\title{
MULTI-ELEMENTAL ANALYSIS OF CREPIS SAHENDI BOISS GROWN IN IRAQI KURDISTAN REGION USING ICP-OES/ICP-MS TECHNIQUES
}

\author{
Peshawa Shafiq Osw *, and Pshtiwan Adel Masum
}

\author{
Dept. Chemistry, College of Science, Salahaddin University, Erbil, Kurdistan Region, Iraq - peshawa.osw@su.edu.krd
}

\begin{abstract}
:
Crepis sahendi Boiss is perennial plant growing in Iraqi Kurdistan region. Traditionally, it is used for the treatment of abdominal ache. The objective of this study is to evaluate the element contents of root, stem, leaf and flower of $C$. sahendi, which were determined using microwave assisted digestion followed by ICP-OES/ICP-MS techniques. Sixty-five elements were analyzed from the studied plant parts. Element concentrations of Pt, Pd and Re have not been detected in any parts of the studied plant. Some elements were present only in specific parts, such as; Ta, Ti, U, Ho, Lu, Tm, Yb W, In and Te. The rest of the elements were detected in all parts of $C$. sahendi in different concentrations. Lead and Arsenic reach the toxic concentrations in flower with 45.9 $\mathrm{ppm}$ and $25.6 \mathrm{ppm}$ respectively. Chromium was also showed in a toxic ratio within root, leaf and flower with $8.04 \mathrm{ppm}, 7.43 \mathrm{ppm}$ and $3.47 \mathrm{ppm}$ respectively. The determination of metals as toxic ratio was depended on the WHO references. The presence of these toxic heavy metals in such a ratio in the selected parts of $C$. sahendi make us believe that this traditional plant is not safe to be used by consumers in the sampling area.
\end{abstract}

KEYWORDS: Crepis sahendi, Toxic metals, Microwave digestion, ICP-OES/ICP-MS.

\section{INTERODUCTION}

Herbal plants are important and widely used in folk therapeutic treatments worldwide. It is well known that about $75 \%$ of the world's population relies on non-conventional medicines or herbal plants. These plants are sometimes contaminated with toxic heavy metals depending on their nature and origin, which impose serious health risks on consumers (Xudong et al., 2011). Herbal drugs may be contaminated easily during growing and processing. Consequently, recent developments have been reported in the environmental pollution control and treatment to reduce its undesired effects on the human health (Pesavento et al., 2009; Sitko et al., 2012).

Minerals are inorganic substances, present in all body tissues and fluids and their presence is necessary for the maintenance of certain physicochemical processes which are essential to life (Malhotra, 1998). The elemental contents of the medicinal plants are very essential and need to be screened for their quality control (Shazia et al., 2010). In recent years, several authors all across the world reported many studies on the importance of elemental constituents of the herbal drug plants which enhanced the awareness about trace elements in these plants. Most of these studies concluded that essential metals could also produce toxic effects when the metal intake is in high concentrations, whereas non-essential metals are toxic even in very low concentrations for human health (Wong et al., 1993; Sharma et al., 2009; Sheded et al., 2006; Koe and Sari, 2009; Basgel and Erdemoglu, 2006; Ajasa et al., 2004; Kanias and Loukis, 1987). Before the metal detection, the mineralization procedure is of great interest for obtaining accurate, precise and reliable results in the metallic analysis of medicinal plants. Many procedures have been reported for the pretreatment step, namely, the wet method, the dry ashing procedure, and the microwave digestion method. Microwave digestion method has many advantages including rapid, efficient and has reproducible results (Ibrahim, 2014).

In order to assess the essential and toxic heavy metals in herbal plants, several techniques have been used after the dissolution step, such as: colorimetric, polarimetry, voltmetry, capillary electrophoresis, neutron activation analysis, scanning electron microscopy-energy dispersive X-ray (SEM-EDX) analyzer, flame atomic absorption spectrometry (FAAS) and electrothermal AAS (ETAAS), inductively coupled plasmaatomic emission spectroscopy (ICP-AES) which is same to inductively coupled plasma optical emission spectrometry (ICPOES), inductively coupled plasma mass spectrometry (ICP-MS). ICP technique is one of the most powerful techniques for its quick multi-elemental analysis capability and high sensitivity (Ibrahim et al., 2015; Ibrahim, 2014; Umran et al., 2012).

Crepis is a genus within the Compositae (Asteraceae) family, comprises with over 200 species and is distributed throughout the northern hemisphere and Africa. The genus presumably originated in the Pamir/Altai region in Central Asia. Presently the center of diversity is the circum-Mediterranean area (Babcock, 1947). Crepis sahendi Boiss is scapigerous perennial plant, 17$45 \mathrm{~cm}$ high, with woody rootstock and deep tap root. It is grow on rocky stony slopes and screes to snow line, 2400-3660 m. Crepis sahendi is locally named Mam Miran, and traditionally used for the treatment of abdominal ache. Mainly it was distributed in Kurdistan region, Transcaucasia, North West Iran, Iran-Turkey element (Davis, 1975) (Figure 1).

Globally, only one investigation has been recorded on the Crepis sahendi Boiss, which included a preliminary phytochemical screening (Masum and Osw, 2016). Therefore the present study was aimed firstly, to estimate the concentration of some macronutrients, micronutrients and trace toxic metals in $C$. sahendi from Hallgurd Mountain in Erbil governorate using ICPOES/ ICP-MS techniques after pretreatment by microwave digestion system. Secondly, increase the awareness of the local consumers about using the medicinal plants in the contaminated area.

\footnotetext{
* Corresponding author
} 


\section{MATERIALS AND METHODS}

\subsection{Chemicals}

All chemicals used were of analytical grade. Precision and accuracy of the method were evaluated analyzing a SRM NIST 1515 (Apple Leaves) and 1572a (Citrus Leaves). The resulting all the solutions were analyzed by ICP-OES (Agilent 725-ES Radial) and ICP-MS (Agilent 7700x) with external calibration method. Multi-element calibration solution was obtained from dilution of $1 \%(\mathrm{v} / \mathrm{v}) \mathrm{HNO}_{3}$ of stock standard solution ICP multi-element standard solution XXI, for MS (30 elements $10 \mathrm{mg} / \mathrm{L}$ ) Certipur ${ }^{\circledR}$; ICP multielement standard solution IV, (23 elements $1000 \mathrm{mg} / \mathrm{L})$ Certipur ${ }^{\circledR}$; Rare Earth ICP-MS Standard (10 mg/L) Merck Millipore. Other blends were prepared to add single element standard solution taking into account compatibility. Mercury and Antimony standard solution were used separately.

\subsection{Instrument}

An inductively coupled plasma-optical emission spectrometry and inductively coupled plasma-mass spectrometry was taken at ALS Laboratory (Sevilla, Spain).

\subsection{Operating conditions of ICP-OES}

RF incident power $(1.2 \mathrm{~kW})$, Plasma argon flow rate $(15 \mathrm{~L} /$ $\mathrm{min})$, Auxiliary argon flow rate $(1.5 \mathrm{~L} / \mathrm{min})$, Nebulizer argon flow rate $(0.85 \mathrm{~L} / \mathrm{min})$, Number of readings per replicate (3).

\subsection{Operating conditions of ICP-MS}

$\mathrm{RF}$ incident power $(1.3 \mathrm{~kW})$, Plasma argon flow rate (15 $\mathrm{L} / \mathrm{min})$, Auxiliary argon flow rate $(0.7 \mathrm{~L} / \mathrm{min})$, Nebulizer argon flow rate $(0.87 \mathrm{~L} / \mathrm{min})$, Dwell time $(30 \mathrm{~s})$, Number of readings per replicate (3). Polyatomic interferences for complex matrix were removed employing a collision/reaction cell (Octopole Reaction System).

\subsection{Plant material}

Crepis sahendi Boiss was collected during July 2012 from Hallgurd Mountain, Soran Judiciary-Erbil governorate. The collected fresh plant materials (Figure 1) were classified and identified in ESUH (Education Salahaddin University Herbarium) by Professor Dr. A. H. Al-Khayat and Dr. A. Sh. Sardar.

The plant materials were collected, washed thoroughly with tab water, shade dried, homogenized to a fine powder $(0.8$ $\mathrm{mm}$ mesh) and stored in plastic bottles in a dark place at room temperature until the time of use.

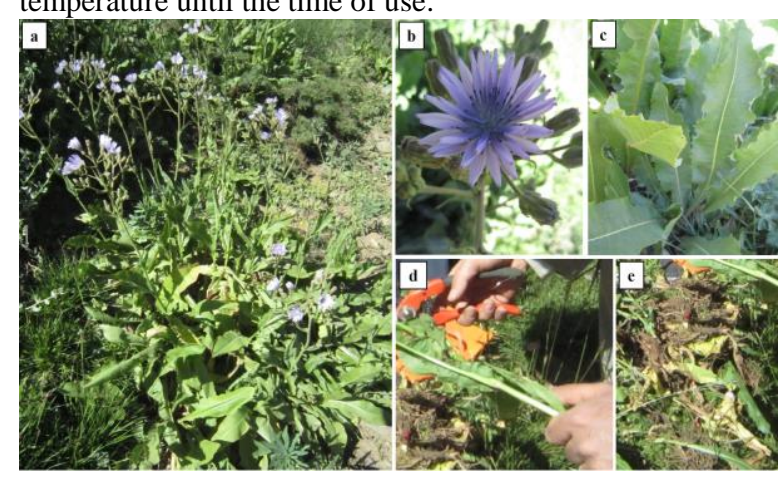

Figure 1. Morphology of Crepis sahendi Boiss: (a) The whole plant, (b) Flower, (c) Leave, (d) Stem and (e) Root
Table 1. Major, minor and heavy metal elemental content of Crepis sahendi Boiss parts (flower, root, leave and stem)

\begin{tabular}{|c|c|c|c|c|c|c|}
\hline \multirow[t]{2}{*}{ Elements } & \multirow[t]{2}{*}{ Symbol } & \multirow{2}{*}{$\begin{array}{l}\text { LOD } \\
(\mathrm{ppm})\end{array}$} & \multicolumn{4}{|c|}{$\begin{array}{l}\text { Crepis Sahendi elemental content in } \\
(\mathrm{ppm})\end{array}$} \\
\hline & & & CF & CR & CL & CS \\
\hline Aluminum & $\mathrm{Al}$ & 100 & 400 & 900 & 700 & 100 \\
\hline Antimony & $\mathrm{Sb}$ & 0.01 & 1.47 & 0.01 & 0.03 & 0.01 \\
\hline Arsenic & As & 0.01 & 25.6 & 0.18 & 0.26 & 0.01 \\
\hline Aurum & $\mathrm{Au}$ & 0.0002 & 0.004 & 0.0006 & 0.0009 & 0.0002 \\
\hline Barium & $\mathrm{Ba}$ & 0.1 & 3 & 15.7 & 7.3 & 7.4 \\
\hline Beryllium & $\mathrm{Be}$ & 0.01 & 0.02 & 0.03 & 0.03 & $<0.01$ \\
\hline Bismuth & $\mathrm{Bi}$ & 0.001 & 0.254 & 0.006 & 0.014 & 0.003 \\
\hline Boron & $\mathrm{B}$ & 1 & 25 & 17 & 43 & 19 \\
\hline Cadmium & $\mathrm{Cd}$ & 0.001 & 0.223 & 0.228 & 0.082 & 0.087 \\
\hline Calcium & $\mathrm{Ca}$ & 100 & 6200 & 7700 & 21900 & 7200 \\
\hline Cerium & $\mathrm{Ce}$ & 0.003 & 0.544 & 0.991 & 0.755 & 0.081 \\
\hline Cesium & Cs & 0.005 & 0.037 & 0.042 & 0.049 & 0.011 \\
\hline Chromium & $\mathrm{Cr}$ & 0.01 & 3.47 & 8.04 & 7.43 & 1.44 \\
\hline Cobalt & $\mathrm{Co}$ & 0.002 & 0.66 & 1.12 & 0.689 & 0.119 \\
\hline Copper & $\mathrm{Cu}$ & 0.01 & 24.6 & 8.56 & 6.72 & 7.21 \\
\hline Dysprosium & Dy & 0.002 & 0.038 & 0.092 & 0.058 & 0.006 \\
\hline Erbium & $\mathrm{Er}$ & 0.002 & 0.019 & 0.054 & 0.031 & 0.002 \\
\hline Europium & $\mathrm{Eu}$ & 0.002 & 0.011 & 0.031 & 0.021 & 0.003 \\
\hline Gadolinium & $\mathrm{Gd}$ & 0.002 & 0.045 & 0.109 & 0.068 & 0.006 \\
\hline Gallium & $\mathrm{Ga}$ & 0.004 & 0.144 & 0.297 & 0.201 & 0.022 \\
\hline Germanium & $\mathrm{Ge}$ & 0.005 & 0.015 & 0.028 & 0.016 & 0.005 \\
\hline Hafnium & $\mathrm{Hf}$ & 0.002 & 0.013 & 0.024 & 0.015 & 0.002 \\
\hline Holmium & Ho & 0.002 & 0.007 & 0.02 & 0.011 & $<0.001$ \\
\hline Indium & In & 0.005 & 0.008 & $<0.005$ & $<0.005$ & $<0.005$ \\
\hline Iron & $\mathrm{Fe}$ & 0.1 & 1290 & 1190 & 770 & 96 \\
\hline Lanthanum & $\mathrm{La}$ & 0.002 & 0.259 & 0.495 & 0.364 & 0.046 \\
\hline Lead & $\mathrm{Pb}$ & 0.01 & 45.9 & 0.56 & 0.66 & 0.14 \\
\hline Lithium & $\mathrm{Li}$ & 0.1 & 0.4 & 0.8 & 0.6 & 0.1 \\
\hline Lutetium & $\mathrm{Lu}$ & 0.001 & 0.003 & 0.005 & 0.003 & $<0.001$ \\
\hline Magnesium & $\mathrm{Mg}$ & 10 & 2200 & 2160 & 10650 & 4120 \\
\hline Manganese & $\mathrm{Mn}$ & 0.1 & 34.5 & 51 & 51.2 & 39.7 \\
\hline Mercury & $\mathrm{Hg}$ & 0.001 & 0.103 & 0.006 & 0.025 & 0.013 \\
\hline Molybdenum & Mo & 0.01 & 0.6 & 0.35 & 0.5 & 0.1 \\
\hline Neodymium & $\mathrm{Nd}$ & 0.001 & 0.226 & 0.504 & 0.373 & 0.043 \\
\hline Nickel & $\mathrm{Ni}$ & 0.04 & 8.31 & 10.35 & 7.05 & 2.26 \\
\hline Niobium & $\mathrm{Nb}$ & 0.002 & 0.047 & 0.139 & 0.067 & 0.005 \\
\hline Palladium & $\mathrm{Pd}$ & 0.001 & $<0.001$ & $<0.001$ & $<0.001$ & $<0.001$ \\
\hline Phosphorus & $\mathrm{P}$ & 10 & 3520 & 900 & 1970 & 810 \\
\hline Platinum & $\mathrm{Pt}$ & 0.001 & $<0.001$ & $<0.001$ & $<0.001$ & $<0.001$ \\
\hline Potassium & $\mathrm{K}$ & 100 & 21500 & 10000 & 19700 & 14800 \\
\hline Praseodymium & $\operatorname{Pr}$ & 0.002 & 0.068 & 0.129 & 0.09 & 0.009 \\
\hline Rhenium & $\mathrm{Re}$ & 0.001 & $<0.001$ & $<0.001$ & $<0.001$ & $<0.001$ \\
\hline Rubidium & $\mathrm{Rb}$ & 0.01 & 15.9 & 4.57 & 9.87 & 7.43 \\
\hline Samarium & $\mathrm{Sm}$ & 0.003 & 0.061 & 0.112 & 0.086 & 0.008 \\
\hline Scandium & $\mathrm{Sc}$ & 0.01 & 0.17 & 0.24 & 0.18 & 0.1 \\
\hline Selenium & $\mathrm{Se}$ & 0.005 & 0.068 & 0.037 & 0.035 & 0.01 \\
\hline Silver & $\mathrm{Ag}$ & 0.001 & 0.122 & 0.006 & 0.017 & 0.009 \\
\hline Sodium & $\mathrm{Na}$ & 10 & 280 & 420 & 550 & 200 \\
\hline Strontium & $\mathrm{Sr}$ & 0.02 & 4.87 & 32.8 & 31.8 & 21.8 \\
\hline Sulfur & $S$ & 100 & 3000 & 1200 & 3000 & 700 \\
\hline Tantalum & Ta & 0.001 & 0.003 & 0.003 & 0.002 & $<0.001$ \\
\hline Tellurium & $\mathrm{Te}$ & 0.02 & $<0.02$ & 0.03 & $<0.02$ & $<0.02$ \\
\hline Terbium & $\mathrm{Tb}$ & 0.001 & 0.007 & 0.018 & 0.011 & 0.001 \\
\hline Thallium & $\mathrm{Tl}$ & 0.002 & 0.079 & 0.01 & 0.008 & 0.003 \\
\hline Thorium & $\mathrm{Th}$ & 0.002 & 0.037 & 0.024 & 0.036 & 0.009 \\
\hline Thulium & $\mathrm{Tm}$ & 0.001 & 0.003 & 0.007 & 0.004 & $<0.001$ \\
\hline Tin & $\mathrm{Sn}$ & 0.01 & 0.18 & 0.07 & 0.07 & 0.09 \\
\hline Titanium & $\mathrm{Ti}$ & 10 & 10 & 60 & 20 & $<10$ \\
\hline Tungsten & $\mathrm{W}$ & 0.01 & 0.07 & 0.01 & $<0.01$ & $<0.01$ \\
\hline Uranium & $\mathrm{U}$ & 0.005 & 0.025 & 0.042 & 0.02 & $<0.005$ \\
\hline Vanadium & $\mathrm{V}$ & 0.05 & 1.24 & 3.36 & 1.87 & 0.27 \\
\hline Ytterbium & $\mathrm{Yb}$ & 0.003 & 0.019 & 0.041 & 0.024 & $<0.003$ \\
\hline Yttrium & $\mathrm{Y}$ & 0.003 & 0.224 & 0.557 & 0.33 & 0.03 \\
\hline Zinc & $\mathrm{Zn}$ & 0.1 & 90.3 & 15.7 & 19 & 53.5 \\
\hline Zirconium & $\mathrm{Zr}$ & 0.02 & 0.3 & 0.77 & 0.33 & 0.07 \\
\hline
\end{tabular}




\subsection{Sample preparation}

One gram of each sample accurately weighted, then transferred to the vessel of the microwave digestion system with $7 \mathrm{ml}$ of ultra-pure concentrated (Sigma-Aldrich) nitric acid $(65-71 \%)$ and $1 \mathrm{ml} \mathrm{H}_{2} \mathrm{O}_{2}$ (Sigma-Aldrich) $(30 \% \mathrm{v} / \mathrm{v})$ and applied to a Microwave digestion program; Power (1000 watts), Ramp Time (10 min), Hold Time (10 min), Temp $\left(180{ }^{\circ} \mathrm{C}\right)$. Then the cooled sample was treated to reduce the acid to a small volume with the same system. The residual sample was transferred quantitatively with Deionized Distilled Water (D.D.W) to a $25 \mathrm{ml}$ polypropylene flask. A blank was also prepared using all the reagents as in samples and SRM preparation procedure and concurrently analyzed (Feng et al., 1999).

\section{RESULTS}

Sixty-five elements were analyzed from root, stem, leaf and flower of the studied plant. In the element analysis, Pt, Pd, and Re have not been detected in any parts of the studied plant. Some elements were present in specific parts, for instance; Ta, Ti, U, Ho, Lu, Tm and $\mathrm{Yb}$ elements were detected in all plant parts except the stem, whereas $\mathrm{W}$ was present only in flower and the root. In another hand, In was found only in the flower, while, Te was detected in the roots of the studied plant. The rest of the elements were detected in all parts of Crepis sahendi in different concentrations as shown in Table 1. Lead and arsenic were found in a significant concentration in the flower which is $45.9 \mathrm{ppm}$ and $25.6 \mathrm{ppm}$ respectively, and also chromium was found at a high level in root $(8.04 \mathrm{ppm})$, leaf $(7.43 \mathrm{ppm})$ and flower (3.47 ppm).

\section{DISCUSSION}

The elements in the medicinal plants play an important role in the treatment of diseases. It is important to have a good quality control for herbal medicines to protect consumers from contamination. Therefore, it is a critical challenge to determine the concentration of essential elements, heavy and toxic metals in herbal plants in order to ensure that their levels meet the related standards or regulations limiting their concentration in herbal drugs. Toxic and heavy metals such as $\mathrm{Pb}, \mathrm{As}$, and $\mathrm{Cr}$ are widely considered as potential and major contaminants in herbal medicine. Consequently, their quantification in popular medicinal plants is essential for herbal drugs quality control purposes (WHO, 2007).

The permissible limit for $\mathrm{Pb}$ set by FAO/ WHO (1984) in edible plants was $0.43 \mathrm{ppm}$. However, for medicinal plants the $\mathrm{Pb}$ limit was $10 \mathrm{ppm}$ set by Canada, China, Malaysia, Republic of Korea, Singapore, Thailand, and WHO. While, for As it was 5 ppm (WHO, 2007). The concentration of $\mathrm{Pb}$ and As in the flower of Crepis sahendi are $45.9 \mathrm{ppm}$ and 25.6 ppm respectively, compared to those proposed by WHO in 2007; it was found that accumulated $\mathrm{Pb}$ and As are much more above the permissible limits. Lead causes both acute and chronic poisoning, and also poses adverse effects on kidney, liver, vascular and immune system (Heyes, 1997). Chronic ingestion of inorganic As causes multisystem adverse health effects. Long expose of arsenic in high dose causes characteristic skin manifestation, renal disease, neurological effects, cardiovascular disease, chronic lung disease, cerebrovascular disease, reproductive effects and cancers of skin, lungs, liver, kidney and bladder (Wang et al., 2003).

Chromium concentration was found in a high level in the root, leaf and flower of the studied plant, especially in the root and the leaf which are $8.04 \mathrm{ppm}$ and $7.43 \mathrm{ppm}$ respectively. After comparison, $\mathrm{Cr}$ limit in the studied plant with those proposed by FAO/WHO (1984) it was found that the plant accumulates $\mathrm{Cr}$ above this limit. However, for medicinal plants the WHO (2007) limits not yet been established for Cr. Although in raw medicinal plants, permissible limits for $\mathrm{Cr}$ set by Canada were $2 \mathrm{ppm}$ (WHO, 2007). Chronic exposure to $\mathrm{Cr}$ may result in liver, kidney and lung damage (Zayed and Terry, 2003).

There are several factors which affect the elemental content of the plants, such us underground water, soil, air pollution and the toxicity of the plant itself. The sampling area of the studied plant considered to be polluted due to a series of wars happened in the last four decades between the Peshmarga (Kurdish resistance force) and the Iraqi army, and the eight-year war between the two neighbor countries Iraq and Iran. Various destructive weapons were used in this area during these wars. Actually, mines are still present in many spots, this may illustrate the high level of some heavy metal in Crepis sahendi such as $\mathrm{Pb}$, As and $\mathrm{Cr}$. The presence of these toxic heavy metals with an impermissible ratio in the selected parts of the studied plant make us believe that this traditional plant is not safe for use by consumers in the sampling area. Also we suggest a serious of further investigations on all other plant species growth in this contaminated region, especially these which have being used by the residents or their cattle.

\section{CONCLUSION:}

This finding which is the first report on the multi-element analysis of Crepis sahendi Boiss suggested that $\mathrm{Pb}$ and $\mathrm{As}$ (in flower) and $\mathrm{Cr}$ (in the root, leaf and flower) is much higher than the WHO permissible limits. Therefore, the root, leaf and flower of the Crepis sahendi are not safe for consumption in the sampling area.

\section{ACKNOWLEDGEMENTS}

The authors would like to thank all staff in Chemistry Department, College of Science-Salahaddin University- Erbil for their help during all research intervals involved in the work. We would like to thanks, Professor Dr. A. H. Al-Khayat and Dr. Abdullah Sh. Sardar for the botanical identification. Many thanks to Dr. Mudhir Surchi and Dr. Goran Qadir for their advice and assistances. Eventually, acknowledge with many thanks to ALS laboratory group (SL), Spain.

\section{REFERENCES}

Ajasa, M., Bello, O., Ibrahim, O., Ogunwande, A. and Olawore, O. (2004). Heavy trace metals and macronutrients status in herbal plats of Nigeria. Food Chem., 85, 67-71.

Babcock, E. (1947). The Genus Crepis. Part One: The Taxonomy, Phylogeny, Distribution and Evolution of Crepis. University of California Publications 21. University of California Press, Berkeley \& Los Angeles.

Basgel, S. and Erdemoglu, S. (2006). Determination of mineral and trace elements in some medicinal herbs and their infusions consumed in Turkey. Sci. Total Env., 359, 82-89.

Davis, P. (1975). Flora of Turkey and the East Aegean Islands (Vol. 5). Edinburgh: Edinburgh University Press.

FAO/WHO (1984). Contaminants. In Codex Alimentarius, (Vol. XVII), ( $1^{\text {st }}$ ed.). FAO/WHO, Codex Alimentarius Commision, Rome.

Feng, X., Wu, S., Wharmby, A. and Wittmeier, A. (1999). Microwave digestion of plant and grain standard reference materials in nitric and hydrofluoric acids for multi-elemental determination by inductively coupled plasma mass spectrometry. Journal of Analytical Atomic Spectrometry, 14, 939-946.

Heyes, R. (1997). The Carcinogenicity of metals in humans. Cancer Causes Control, 8, 371-385. 
Ibrahim, A. (2014). Determination of some mineral and heavy metals in Saudi Arabia popular herbal drugs using modern techniques. Afr. J. Pharm. Pharmacol., 8, 893-898.

Ibrahim, M., Hussain, F., Zanoni, G. and Vidari, G. (2015). J. Pharm. Sci. Innov., 4, 165-167.

Kanias, G. and Loukis, A. (1987). Determination and correlation of active consitituents and trace elements in the medicinal plants Thymus capitatus Hffm. and Link, Frezenius Z. Analyt. Chem., 327, 355-357.

Koe, H. and Sari, H. (2009). Trace metal contents of some medicinal, aromatic plants and soil samples in the Mediterranean region, Turkey. J. Appl. Chem. Res., 8: 52-57.

Malhotra, V. (1998). Biochemistry for Students. (10 ${ }^{\text {th }}$ ed.). Jaypee Brothers Medical Publishers (P) Ltd, New Delhi, India.

Masum, P. and Osw, P. (2016). Preliminary phytochemical screening of various extracts for five plants species in Iraqi Kurdistan region. Journal University of Zakho, 4A, 8793.

Pesavento, M., Alberti, G. and Biesuz, R. (2009). Analytical methods for determination of free metal ion concentration, labile species fraction and metal complexation capacity of environmental waters: A review. Analytica Chimica Acta, 631, 129-141.

Sharma, K., Agrawal, M. and Marshall, M. (2009). Heavy metals in vegetables collected from production and market sites of a tropical urban area of India. Food Chem. Toxicol., 47, 583-591.

Shazia, J., Muhammad, T., Sardar K. and Muhammad Q. (2010). Determination of major and trace elements in ten important folk therapeutic plants of Haripur basin Pakistan, Journal of Medicinal Plants Research, 4, 559566.

Sheded, G., Pulford, I. and Hamed, I. (2006). Presence of major and trace elements in seven medicinal plants growing in the South-Eastern Desert. Egypt. J. Arid Env., 66, 210-217.

Sitko, R., Zawisza, B. and Malicka, E. (2012). Modification of carbon nanotubes for preconcentration, separation and determination of trace-metal ions. Trends in Analytical Chemistry, 37, 22-31.

Umran, H., Canan, O., Sermin, C., Ali, O. and Serap, E. (2012). Major-minor element analysis in some plant seeds consumed as feed in Turkey. Natural Science, 4, 298-303.

Wang, S., Chiou, J., Chen, C., Tseng, C., Chou, W., Wang, C., Wu, T. and Chang, L. (2003). Prevalence of Non-InsulinDependent Diabetes Mellitus and related vascular disease in southwestern arseniasis-endemic and non-endemic areas in Taiwan. Environ. Hlth. Perspect., 111, 155-159.

WHO (2007). WHO guidelines for assessing quality of herbal medicines with reference to contaminants and residues, Spain.

Wong, M., Tan, P. and Wee, Y. (1993). Heavy metals in some of Chinese herbal plants. Biol. Trace Elem. Res., 36, 135142.

Xudong, Y., Robert, L. and Zhiqian, W. (2011). Analytical methods for heavy metals in herbal medicines: a review. Phytochem. Anal., 22, 189-198.

Zayed, A. and Terry, N. (2003). Chromium in the environment: factors affecting biological remediation. Plant Soil, 249, $139-156$. 